\title{
ИСТОРИЯ
}

ПОЗНЯК Татьяна Зиновьевна,

канд. ист. наук, старший научный сотрудник Института истории, археологии и этнографии народов Дальнего Востока ДВО РАН (г. Владивосток).

Электронная почта: tzpoznyak@mail.ru

\section{Опыт легализации опиокурения во Владивостоке в начале XX в.}

УДК 947.084.34(571.6)

Дальний Восток,

Владивосток, миграиця, китайские мигранты, опиокурение, полииця, коррупиия

1 Написание данного термина в статье приведено в соответствии с современными правилами орфографии, включая приведённые тексть источников, где в оригинале писалось «опиекурение».

Для ичитирования:

Позняк Т. 3. Опыт легализации опиокурения во Владивостоке в начале ХХ в. // Известия Восточного института. 2021. № 1. C. 6-19. DOI https://doi. org/10.24866/2542-1611/2021 $1 / 6-19$
DOI https://doi.org/10.24866/2542-1611/2021-1/6-19

Статья посвящена одному эпизоду из истории длительной борьбы с опиокурением и китайскими притонами на российском Дальнем Востоке во второй половине XIX - начале $\mathrm{XX}$ в. Начиная с 1890-х годов представители местной власти и общественности неоднократно предлагали в качестве меры борьбы с притонами и взяточничеством полиции легализовать курение опиума. Единственными, кто попытался реализовать её на практике, были военный губернатор Приморской области и полицмейстер Владивостока. Однако ввиду непродолжительности указанного опыта инициаторам не удалось убедить вышестоящее начальство в его эффективности.

Проблема тайных притонов в дальневосточных городах и борьба с ними неоднократно оказывалась в поле зрения региональной историографии, большинство исследований посвящены политике региональной администрации в отношении китайских мигрантов, их авторы анализируют различные аспекты бесконечной и часто не достигающей цели борьбы с производством и употреблением опиума в регионе $[1 ; 2 ; 6 ; 7$; $8 ; 12]$. В ряде статей анализируются материалы расследований сращивания местной полиции с организованной китайской преступностью, и в некоторых из них фигурирует полицмейстер Владивостока Г. И. Лединг [2; 9; 10]. Однако рассматриваемый в статье опыт легализации опиокурилен ещё не получил освещение в научной литературе.

Цель статьи - проанализировать один из неизвестных эпизодов борьбы региональной администрации с опиокурением $^{1}$ и китайскими притонами в дальневосточном регионе - попытку их легализации, сторонники этой идеи считали её эффективным способом искоренения взяточничества местной полиции и избавления от притонов.

Основным источником исследования выступает одно из дел фонда 702 «Приамурского генерал-губернатора» РГИА ДВ, где сосредоточена переписка канцелярии генерал-губернатора с военными губернаторами Амурской и Приморской областей, журналы совещаний, материалы ревизий, рапорты, протоколы дознания полиции. Собранные в деле разновременные документы (с 1890 по 1917 гг.) посвящены борьбе с производством и употреблением опиума (Российский государственный исторический архив Дальнего Востока - далее РГИА ДВ. Ф. 702. Оп. 3. Д. 151. 237 л.). 
Главными действующими лицами в рассматриваемой истории выступают военный губернатор Приморской области Василий Егорович Флуг, занимавший эту должность с 19 сентября 1905 г. до 1 января 1910 г. [4, с. 458-459] и полицмейстер г. Владивосток Генрих Иванович Лединг, назначенный исполнять должность высочайшим приказом от 26 июня 1906 г., и утверждённый в ней 8 февраля 1908 г. (РГИА ДВ. Ф. 702. Оп. 4. Д. 670. Л. 193). Приамурским генерал-губернатором с 1905 по 1910 год был Павел Фёдорович Унтербергер. Необходимо заметить, что с приходом к власти в областях и генерал-губернаторстве новых лиц, борьба со старым злом - притонами в азиатских кварталах - обычно активизировалась, но часто без учёта опыта предшественников [12, с. 250-268].

На дело о легализации опиокурения во Владивостоке Приамурский генерал-губернатор вынужден был обратить внимание из-за жалобы китайцев на имя Председателя Совета министров П. А. Столыпина. В этом деле, как и в других подобных [10, с. 24-32], вырисовывается наличие в городе двух противоборствующих групп, назовём их условно: «группа китайцев из Харбина» - «противники легализации опиокурения», полицмейстер и китайцы - сторонники его легализации.

Борьба полиции с опиокурением и тайными притонами в дальневосточных городах осложнялась сплочённостью китайцев, их изощрённостью в плане обхода законов, высокой доходностью данного промысла, а также взяточничеством представителей полиции. Главной проблемой с точки зрения региональной администрации был не вред здоровью китайцев и ущерб их благосостоянию от игорной и наркотической зависимости (хотя и это заботило российские власти), а падение нравов, развращение полиции, получавшей от «крышевания» тайных притонов нелегальные доходы, существование организованной преступности и соучастие в ней полиции и чиновников областной администрации [12, с. 267].

Особенности организации тайных притонов, затруднявшие борьбу полиции с ними, изложены, например, в рапорте помощника полицмейстера Владивостока Пестова от 12 апреля 1904 г. на имя ВГПО: «...опиокурильни и банковки во Владивостоке все переносные в особенности банковки. Содержатели квартир китайцы разрешают банковщику открыть игру у себя в помещении за плату от 70 коп. до 2 руб. в час в известное время дня или ночи, но не больше[,] как часа на 4, причем сторожа китайцы становятся по всем входам и на улице. В летнее время банковки устраиваются на кунгасах и шаландах, а так как особых сложных приспособлений игры в банковку и опиокурильни не представляют, плата же хозяину квартиры за несколько часов очень значительна, а игра продолжается всего несколько часов, то можно утвердительно сказать, что опиокурильни и банковки бывают во всех китайских помещениях всего Владивостока, а не специальных отдельных домах. Китайцы[,] поигравши часа два в одном доме, переходят сейчас в другой, это делается для скрытия игры, а также для сбора новых игроков, при том проигравшие китайцы глубоко уверены, что с переходом их в другое помещение, счастье им улыбнется и они выиграют. Всем банковщикам китайские купцы, содержатели харчевен очень оказывают особое покровительство, по той причине, что китайцы на свои трудовые деньги ничего не покупают, а на выигранные деньги смотрят, как на средство доставления себе всевозможных удовольствий...» (РГИА ДВ. Ф. 702. Оп. 3. Д. 151. Л. 68-68об.).

Существование притонов опиокурения, нелегальной проституции, азартных игр на дальневосточной окраине Российской империи не было секретом ни для полиции, ни для общественности. В даль- 
невосточных городах борьба с ними сводилась к полицейским облавам, выявлению и закрытию притонов. На пойманных нарушителей составляли протоколы, которые передавались мировым судьям, виновные несли наказание по ст. ст. 46, 106 Устава о наказаниях, налагаемых мировыми судьями, а предметы опиокурения уничтожались. Задержанные в ходе облав китайцы после суда по постановлениям военного губернатора как порочные иностранцы в административном порядке высылались на родину. Результативности этой борьбы мешало множество обстоятельств: на месте преступления часто задерживали не содержателей притонов, а посетителей, содержатели же уходили от ответственности, и притон продолжал существовать; если же наказанию подвергался владелец, то небольшие штрафы при высокой доходности промысла были не слишком обременительны для него; мировые суды были загружены работой и дела нарушителей рассматривались медленно; высланные на родину «порочные иностранцы» через некоторое время вновь оказывались на российской территории и пр. [3, с. 121-123; 12, с. 262-263].

Первоначально военный губернатор В. Е. Флуг и полицмейстер Г. И. Лединг пытались внедрить запретительные способы борьбы с притонами, в частности, предлагали генерал-губернатору привлекать к ответственности за нарушения домовладельцев, в домах которых полиция обнаруживала притоны, а не только притоносодержателей и задержанных на месте преступления опиокурильщиков и, главное, настаивали, что делать это необходимо в административном, а не судебном порядке. В письме от 4 декабря 1906 г. В. Е. Флуг писал: «Несмотря на предпринимаемые до сих пор меры к обнаружению и искоренению запрещенных азартных игр между проживающими во Владивостоке китайцами, игорные дома, в которых скрывается самый неблагонадежный китайский элемент и которые служат не редко главным центром притона китайских разбойников (хунхузов), всетаки существуют в весьма значительном числе. Обыкновенно содержатели подобных игорных домов, для скрытия запрещенных азартных игр, меняют дома, перенося игру то в одно, то в другое место кварталов китайского населения и если, не смотря на это, все-таки попадаются в руки полиции, то отделываются незначительным денежным взысканием не свыше 50 руб., налагаемым на них приговорами Мировых Судей, заплатить которые для содержателя игорного дома или устроителя игры ничего не значит в виду выгодности предприятия, покрывающего с избытком подобные расходы». Флуг сообщил также о просьбе полицмейстера издать обязательное постановление, которое бы вводило ответственность «домовладельцев и квартирохозяев г. Владивостока» и обязывало их «не допускать в своих домах и квартирах ни игры в банковку, ни опиокурения», а в случае нарушения «виновных привлекать строгой ответственности в административном порядке» (РГИА ДВ. Ф. 702. Оп. 3. Д. 151. Л. 86-86об.).

Однако П.Ф. Унтербергер в ответном письме от 16 декабря 1906 г. не согласился с предложением В.Е. Флуга, полагая издание такого постановления «рискованным», поскольку эта мера предоставит «склонным к злоупотреблениям чинам низшей городской полиции широкий простор для всякого рода произвола по отношению к домовладельцам и квартиронанимателям из китайцев...». Он настаивал, что более целесообразно оставить в силе действующий порядок 
привлечения виновных в допущении в своих домах и квартирах недозволенных игр и опиокурения к судебной ответственности, нацелив все усилия полиции к обнаружению и закрытию всякого рола притонов в среде китайского населения» (РГИА ДВ. Ф. 702. Оп. 3. Д. 151. Л. 89-90об.).

Новый виток переписки между генерал-губернатором и военным губернатором Приморской области произошёл в начале 1908 г. и был вызван самовольным решением губернатора и полицмейстера легализовать опиокурильни.

В декабре 1907 г. несколько «представителей китайского населения Харбина» написали прошение на имя Председателя Совета Министров П. А. Столыпина. Это письмо достойно длинной цитаты: «Около трех лет тому назад Китайская Императрица, усматривая, что курение опиума (опия) приносит громадный вред населению, издала Высочайший Указ, коим воспретила своим подданным курить опий. В начале текущего года этот указ был подтвержден и в настоящее время в Китае как правительственные чиновники, так и весь китайский народ перестали курить опий, ибо за курение опия там строго преследуют; в Китае в настоящее время разрешается курить опий только старикам старше 50 ти лет. Воспрещение курить опий принесло громадную пользу всему китайскому народу, т. к. количество преступлений уменьшилось, уменьшилось количество лиц неспособных к труду и уничтожился непроизводительный расход на покупку опия. Около двух месяцев назад Приморский Военный Губернатор генерал-майор Флуг и Владивостокский Полицмейстер ротмистр Лединг разрешили китайцам И-фу-тинъ, Лю-ды-е, Чи-шен-де и Ян-ши-лоу открыто содержать в г. Владивостоке опиокурильни для китайцев, а также и продавать опий с тем условием, чтобы каждый из указанных китайцев ежемесячно уплачивал в доход русского правительства по 500 руб. в мес., такое разрешение г. полицмейстер Лединг оправдывает тем, что русскому правительству в настоящее время сильно нужны деньги и поэтому только оно разрешает содержать опиокурильни, а раньше запрещало курение опия потому, что не нужно было денег. С момента разрешения в г. Владивостоке опиокурения в Харбин стали приезжать китайцы, которые втянувшись в опиокурение в г. Владивостоке и за невозможностью достать опия в Харбине, падают и умирают. Вред[,] происходящий от курения опия[,] может объяснить каждый врач: если опиокурильщик сразу прекратит курения опия, то он умрет, отучить же от курения опия, возможно только в течение продолжительного времени, постепенно уменьшая порцию опия. Из этого видно, что Владивостокская администрация, разрешая в Владивостоке устройство опиокурилен, тем самым[,] во-первых, как бы издевается над Высочайшим Указом Китайской ИМПЕРАТРИЦЫ[,] коим в Китае воспрещено курение опиума, а во вторых[,] отравляет опием китайское населения г. Владивостока и делает его негодным к труду и проч. На основании изложенного просим распоряжения Вашего Высокопревосходительства: 1) немедленно закрыть в г. Владивостоке все опиокурильни, открытые губернатором Флугом и полицмейстером Ледингом; если же действительно русское правительство так страшно нуждается в деньгах, что вынуждено даже идти на такие поступки, как открытие опиокурилен, то мы, нижеподписавшиеся, соглашаемся ту сумму денег, которую дают опиокурильни, вносить 
2 В документе сохранены все выделения, но исправлены грамматические и пунктуационные ошибки.

3 «Лю-бо-чин-на, Лю-шин-цая, Ванфань-ю, Ян-шинты, Чоу-ю-чина, Пи-хоки, Ли-менчу, Ко-шо-кю, Люхо, Ци-хун-пина, Чжою-до-хо, Чиншу-дзю, Джоу-тыконь и Джан-туюянь». Написание китайских имён приведено как в тексте источника. ежемесячно в доход русской казны из собственных средств[,] только бы опиокурилен не существовало[,] и 2) привлечь к ответственности губернатора Флуга и полицмейстера Лединга за издевательство над ВЫСОЧАЙШИМИ указами Китайской ИМПЕРАТРИЦЫ и за отравление китайского населения опием. г. Харбин, _декабря 1907 года» (РГИА ДВ. Ф. 702. Оп. З. Д. 151. Л. 100об.-101)².

Жалоба китайцев Харбина, как и практика «писем во власть» вообще, являлась типичной для того времени. Такие письма поступали в разные инстанции и от русских, и от китайцев, и широко использовались не только в поисках справедливости, но и для сведения счетов с конкурентами. Как и в других подобных делах, невозможно достоверно определить мотивы, жалоба могла быть написана либо китайцами, действительно заинтересованными в искоренении опиокурения, либо некой группой содержателей опиокурилен и связанных с ними представителей полиции, которые были недовольны установлением монополии, контролируемой Ледингом.

Обращение китайцев из Харбина в высшие эшелоны российской власти не могло остаться без внимания. 8 февраля 1908 г. Приамурскому генерал-губернатору был послан запрос из Управления Главного врачебного инспектора МВД, имеет ли вышеуказанное заявление от представителей китайского населения Харбина о разрешенных «будто бы военным губернатором Приморской области к открытию в г. Владивостоке опиокурильнях ... фактическое основание». В утвердительном случае ему было рекомендовано распорядиться «о немедленном закрытии курилен опия, как не предусмотренных законом и вредных для здоровья населения» (РГИА ДВ. Ф. 702. Оп. 3. Д. 151. Л. 96).

4 марта 1908 г. правитель канцелярии генерал-губернатора К. А. Лакшевиц послал запрос военному губернатору (РГИА ДВ. Ф. 702. Оп. З. Д. 151. Л. 97), и 2 апреля 1908 г. В. Е. Флуг ответил, что «...указанная мера была принята с моего ведома, в виде опыта; побудило же меня к допущению ее, глубокое убеждение, основанное на двухлетнем опыте и знании истории вопроса, что борьба обыкновенными средствами со злом опиокурения среди китайцев не дает решительно никаких результатов, кроме развращения чуть ли не всего состава полиции» (РГИА ДВ. Ф. 702. Оп. З. Д. 151. Л. 98). К письму он приложил копию секретного рапорта № 129 Владивостокского полицмейстера Г. И. Лединга от 25 марта 1908 г. В рапорте полицмейстер приводил губернатору доводы, объяснявшие необходимость такого экстраординарного решения, и его видение ситуации борьбы с тайными притонами в городе.

Как же и почему произошла легализации опиокурилен по версии Г. И. Лединга?

8 сентября 1907 г. ему поступило прошение 14 китайских подданных, проживавших во Владивостоке ${ }^{3}$. Приведем его текст почти полностью: «Нам также хорошо известно, как и Вашему Высокоблагородию, что в городе существует много опиумокурилен ... и что опиумокурение весьма распространено между китайским населением города. Видим мы также бесплодную по результатам борьбу полиции с этим злом, т. к. число опиумокурилен в городе не уменьшается. Происходит это, по нашему глубокому убеждению от того, что с одной стороны численный состав городской полиции недостаточен и кроме того он, 
будучи занят исполнением прямых своих обязанностей по надзору за внешним порядком и спокойствием, не имеет возможности делать частые и тщательные обыски по многочисленным домам, занимаемым китайцами с целью обнаружения принадлежностей опиумокурения и самого опиума, а с другой стороны у китайцев содержателей опиумокурилен существует организованный надзор по охранению спокойного процветания опиумокурения в их притонах. Обыкновенно результаты внезапных и ночных обысков полиции выражается тем, что посетители опиумокурильни, почему либо не успевшие своевременно убежать, задерживаются и подвергаются высылке из города по протоколам полиции, как содержатели опиумокурилен, между тем действительные хозяева таковых ещё ни разу не были задержаны полицией, а потому и оставались безнаказанными, а найденные полицией опиумокурильня через 2-3 дня вновь начинает функционировать. Мы полагаем, что Ваша осведомленность по этому делу не дает Вам возможности отрицать действительную бесплодность борьбы с опиумокурением тем порядком каким эта борьба ведется в настоящее время, а потому не желая оставаться простыми, сторонними зрителями наказания совершенно неповинных китайцев, приобревших пагубную страсть и являющегося последствием ошибочного преследования содержателей опиумокурилен, и вместе с тем руководствуясь соображением, чтобы изданный в нашей империи закон об уничтожении опиумокурения достиг в г. Владивостоке в наивозможно кратчайший срок своей цели, т. к. мы сознаем твердо весь вред приносимый этим злом нашему бедному населению в городе, мы, нижеподписавшиеся, обращаемся к Вашему Высокоблагородию с настоящим прошением.

Идя на встречу Вам, мы просим дать нам срок для полного уничтожения опиумокурения в г. Владивостоке среди столь многочисленного китайского населения, для чего мы и предлагаем наш план действия на Ваше благоусмотрение и, если Вы признаете его подходящим, то просим одобрить его и допустить приводить его в исполнение под Вашим руководством и наблюдением. Мы берем на себя труд зарегистрировать в весьма непродолжительное время опиумокурильни в городе и список этот представить Вам с обозначением имен хозяев опиумокурилен с тем, чтобы содержание таковых не преследовалось полицией в течение шести месяцев, т. к. известно, что для того, чтобы отучить себя от пагубной привычки опиумокурения, надо время для постепенного уменьшения дозы. Дальше мы беремся следить за тем, чтобы незарегистрированные, тайные опиумокурильни были немедленно Вашим распоряжением, по Вашему указанию, закрыты, с хозяевами же их, если они окажутся ослушниками, было бы поступлено по закону (выслать из города). От нас не скроется ни одна тайная опиумокурильня, так как каждый из нас будет иметь определенный район наблюдения. Борясь с тайными опиумокурильнями для их закрытия, мы вместе с тем будем принимать меры к тому, чтобы и число зарегистрированных опиумокурилен постепенно уменьшалось. За вышеуказанный срок мы достигнем того, что к концу срока в городе не останется ни одной опиумокурильни, а попытка к открытию таковой будет нами своевременно предупреждена. Кроме того, на случай, если бы Вы, по истечении этого срока, обнаружили, хотя бы одну опиумокурильню, мы дадим Вам подписку в принятии на себя ответственности как личной, т. е. Вы вольны будете всех нас выслать из 
города с передачею нашим властям для поступления с нами по закону, так и материальной, т. к. Вы вольны будете наложить на нас штраф в определенной сумме и за взысканием этой суммы отвечаем круговою друг за друга порукою. Деньги эти поступят в Ваше распоряжение» (РГИА ДВ. Ф. 702. Оп. 3. Д. 151. Л. 102-103).

Нельзя достоверно утверждать, что инициатива легализации опиокурилен действительно исходила от китайцев, стилистика прошения и используемые аргументы присутствуют и в обращениях полицмейстера в вышестоящие инстанции и в других документах, составляемых представителями региональной власти, поэтому нельзя исключать предварительную взаимную договорённость китайцев и полицмейстера. Многочисленные примеры сговоров китайцев и русских, когда за прошениями и жалобами китайцев стояли русские приставы, чиновники или частные поверенные, свидетельствуют, что и данное прошение могло быть написано по подсказке. Хотя возможно и обратное: китайцы действительно выступили инициаторами, а прошение по их просьбе написано кем-либо из местных так называемых «адвокатов». Написание различных заявлений, судебных прошений по просьбе неграмотных или малограмотных слоёв населения было обычной практикой в Российской империи, и на Дальнем Востоке в том числе $[5$, с. $173-174 ; 10$, с. $28 ; 11$, с. $38-70 ; 13$, с. $134-161]$. Но и в этом случае истинной причиной могло быть желание не отучить постепенно китайцев от опиокурения и закрыть притоны, а получить монополию на их содержание и избежать при этом преследования со стороны полиции.

12 сентября 1907 г. полицмейстер обратился с рапортом к губернатору, в котором писал, что признаёт «...относительную справедливость изложенных в прошении китайцев обстоятельств» и полагает возможным с ведома губернатора «допустить к осуществлению предлагаемый способ китайцами для полного и скорейшего уничтожения опиокурения в городе...». Главная причина отсутствия результатов в борьбе с опиокурением, по мнению полицмейстера, заключалась в том, что «запрещёния и преследования мерами административными подобных явлений, как опиокурение, распространяющееся здесь целыми десятилетиями, влекут за собою преступное обогащение тех лиц, коим поручается непосредственное преследованием этих явлений». Он писал: «...слишком большой соблазн для таких лиц, как околоточные и городовые, скоро обогатиться и легким способом заработать лишний рубль или десять и в большинстве случаев оставаться безнаказанными. От приставов мне приходилось слышать жалобы на околоточных надзирателей в том, что они, для осуществления моих постоянных требований о скорейшем прекращении опиокурения в городе, не встречают поддержки со стороны околоточных, а эти последние жалуются на покровительство городовых тем китайцам, которые дают городовым рубли, а вследствие сего и на плохие результаты обысков при пособничестве таких помощников. За одно это, по подозрению, без фактических данных преследовать и удалять со службы чинов полиции, я считаю невозможным, так как уверен, что вновь принятые чины не избегнут этого же соблазна, а между тем старые имеют за собою опыт и навык по исполнению вполне успешным способом других своих обязанностей, а также более или менее достаточное знакомство с городом говоря вообще...» (РГИА ДВ. Ф. 702. 
Оп. 3. Д. 151. Л. 103-104). Лединг предлагал временно в виде опыта легализовать опиокурильнии обещал принять «меры к тому, чтобы через 6 мес. в городе действительно не было опиокурилен» (РГИА ДВ. Ф. 702. Оп. 3. Д. 151. Л. 103-104). Из вышеприведенного письма Флуга от 3 апреля 1908 г. Унтербергеру мы видим, что губернатор дал санкцию на эту меру.

27 сентября 1907 г. китайцами был составлен список из 247 опиумокурилен, подлежащих легализации, составлен порядок их закрытия и дана подписка: «Мы, нижеподписавшиеся, содержатели опиумокурилен в г. Владивостоке ... даем настоящую подписку г ну полицмейстеру в том, что подробно означенные в особом списке опиумокурильни, существующие в настоящее время в количестве 247 , при постепенном ежемесячном закрытии $1 / 6$ части всего первоначального количества, т. е. по 41 ежемесячно, будут к концу шестимесячного срока, считая с 1 октября 1907 г. т. е. не позже 1 апреля 1908 г. все до единой закрыты. Если же после означенного срока полицией будет обнаружена хотя бы одна опиумокурильня, то мы подвергаемся самой строгой ответственности... В точном исполнении нами этой подписки мы ручаемся круговою друг за друга порукою» (РГИА ДВ. Ф. 702. Оп. З. Д. 151. Л. 1040б.-106).

Владельцами легализованных опиокурилен из этого списка были те самые 14 китайцев, написавших прошение полицеймейстеру 8 сентября 1907 г. В архивном деле сохранились два списка: согласно первому: из 247 заведений 5 находились в Матросской слободке, 55 в Корейской, 187 - в районе Миллионки (3 полицейская часть), согласно второму - 177 заведений располагались в Миллионке, 31 - в Матросской слободке, 39 - в Корейской (РГИА ДВ. Ф. 702. Оп. 3. Д. 151. Л. 105-106).

19 октября 1907 г. полицмейстер приказал приставам 1, 2 и 3 части проверить подведомственные территории и закрыть притоны, не входившие в список. В инструкции приставам он детально объяснил мотивы и суть принятых решений и предупредил об ответственности лиц, уличённых в поборах. В заключение инструкции он писал: «... Все опиокурильни, которые не попали в список, подлежат немедленному закрытию, а хозяева их будут высланы из пределов края. Зарегистрированные же опиокурильни обозначены номерами и разделены на шесть равных частей для постепенного их закрытия; каждая очередная часть закрывается по истечении месяца и, таким образом выйдет, что к 1 апреля 1908 г. все опиокурильни будут закрыты, так сказать, самими хозяевами опиокурилен...». Наблюдение за порядком их закрытия полицмейстер возложил на китайскую полицию во главе с околоточным надзирателем Потаповым или его заместителем; остальные чины полиции должны были оказывать им полное содействие в достижении указанной цели. Лединг сообщил также полицейским, что у хозяев опиокурилен «отобраны подписки в строгом соблюдении ими порядка закрытия опиокурилен и в принятии ими самых энергичных мер чрез своих агентов к обнаружению тайных (незарегистрированных) опиокурилен и к указанию хозяев таковых». Если же после 1 го апреля 1908 г. будет обнаружена в городе хотя одна опиокурильня, указанные хозяева будут нести «ответственность по всей строгости закона». «Строгим и беспощадным образом» полицмейстер обещал преследовать и «всякие поборы с опиокурилен 
как чинами полиции, так и различными китайскими переводчиками и сборщиками якобы для должностных лиц», «уличенные в поборах и вымогательстве будут предаваться суду» (РГИА ДВ. Ф. 702. Оп. 3. Д. 151. Л. 107-107об.).

3 ноября 1907 г. по окончании первого месяца эксперимента околоточный надзиратель Потапов со вверенной ему китайской полицией проверил, закрылись ли они и их соответствие ранее заявленному списку. Оказалось, что китайцы не исполнили условия договора и закрыли не те заведения, которые обещали. Более того, они начали просить разрешения закрывать заведения не в соответствии со списком, а в ином порядке, но обязались за семь дней до контрольной даты предоставлять список закрываемых заведений, и полицмейстер пошёл им навстречу. 4-5 ноября Потапов вновь произвёл проверку и убедился, что договоренное количество опиокурилен было закрыто (РГИА ДВ. Ф. 702. Оп. 3. Д. 151. Л. 108-109).

Однако опыт не был доведён до конца в силу независящих от полицмейстера обстоятельств. С объявлением крепости на осадном положении в связи с революционными событиями Комендант Владивостокской крепости В. А. Ирман 6 ноября 1907 г. издал обязательное постановление № 6 о запрете содержания опиокурилен в городе (РГИА ДВ. Ф. 702. Оп. 3. Д. 151. Л. 100). Владельцы легализованных опиокурилен вынуждены были закрыть (или только отрапортовали полицмейстеру о закрытии) своих заведений. При этом они попытались застраховаться от ответственности за выявленные тайные притоны, которые, надо полагать, продолжали функционировать в городе, несмотря на все договорённости. В прошении полицмейстеру от 9 ноября 1907 г. они писали: «Согласно объявления обязательного постановления г. Коменданта Владивостокской крепости от 6 сего ноября за № 6, мы положительно все свои опиокурильни прекратили и производить не будем, а в случае где в бывших на них помещёниях опиокурилен будут обнаружены опиокурильни, то это будут не от нашего имени, а от имени других лиц и мы не должны привлекаться к ответственности хотя другие с корыстной целью и укажут на наши имена, так как из нас никто производить не будет в действительности и просим таким заявителям не верить...» (РГИА ДВ. Ф. 702. Оп. 3. Д. 151. Л. 109).

Когда же в начале 1908 г. возникла переписка по жалобе «китайцев Харбина» Лединг в секретном рапорте губернатору от 25 марта 1908 г. № 129 подробно изложил все обстоятельства эксперимента по легализации опиокурения в городе, его причины и своё мнение о том, что на самом деле двигало заявителями - «китайцами из Харбина». Полицмейстер писал: «...я руководился отнюдь не соображением сделать опиокурение не преследуемым и дозволенным, а только поставить курение опия китайцами под свой непосредственный контроль и дать возможность лицам, привыкшим к курению, постепенно отвыкнуть от этой страсти. Вместе с тем я сразу ставил предел и конец всяким со стороны недобросовестных чинов полиции поборам с тайных для меня, но явных для них опиокурилен. За такой радикальный прием, не нравящийся подчиненным мне чинам полиции, а также целой плеяде разных тунеядцев как русских, так и китайцев, по преимуществу знающих русский язык и каким то необъяснимым образом имеющих в руках своих визитные карточки весьма разноо- 
бразных должностных лиц в городе и действующих от имени последних, лишившимся сразу своих легких доходов, которые установились здесь чуть ли не годами, посыпались самые различные доносы на меня в различные учреждения и должностным лицам, обвиняющие меня в каких-то с китайцами сделках нечистоплотного характера. Могу только одно сказать, что все эти доносы и кляузы хорошо известны Вашему Превосходительству. Смею надеяться, вы дали должную оценку им. К таким же кляузам, без сомнения, надо отнести по своему содержанию и по форме заявление якобы представителей китайского населения в Харбине на имя его Высокопревосходительства г. Председателя Комитета Министров ${ }^{4}$. По содержанию заявление это - кляуза, потому что никаких сборов с опиокурилен я не произвожу, а напротив того без пощады преследовал и угрожал отдачей под суд уличенных в поборах; равным образом не давал разрешения на открытие опиокурилен от своего имени, а тем более от имени Вашего Превосходительства...» (РГИА ДВ. Ф. 702. Оп. 3. Д. 151. Л. 98об.$100)$.

О результатах переписки по заявлению китайцев из Харбина с военным губернатором вр. и. о. Приамурского генерал-губернатора Н. Н. Мартос 23 апреля 1908 г. (№ 3758) сообщил Министру внутренних дел с препровождением отзыва В. Е. Флуга от 2 апреля 1908 г. № 481 и возвращением жалобы (РГИА ДВ. Ф. 702. Оп. 3. Д. 151. Л. $110-11006$.$) .$

Ещё один рапорт, где излагались обстоятельства рассматриваемого эксперимента, был написан Г. И. Ледингом позднее и в связи с другими обстоятельствами. В феврале 1909 г. в Шанхае планировалось провести международную комиссию (конференцию) по обсуждению мер борьбы с распространением наркотиков. Подготовка к этому мероприятию вызвала очередной подъём интереса к проблеме опиокурения и виток переписки между правительством, дипломатами и региональной администрацией. МВД и Российский императорский генеральный консул в Шанхае попросили Приамурского генералгубернатора предоставить сведения о производстве опиума, опиокурении и борьбе с ним в пределах подведомственной территории. 17 января 1909 г. канцелярия генерал-губернатора отослала соответствующий запрос военному губернатору Приморской области, который 22 января послал таковой же полицмейстеру Владивостока.

«Экстренный» рапорт полицмейстера от 28 января 1909 г. № 2395 губернатору был ответом на этот запрос. В нём Г. И. Лединг выразил убеждённость, что «вышеуказанный опыт, доведенный до конца, дал бы вполне удовлетворительные результаты, т. е. после прошествия 6 ти месяцев в городе не существовало бы ни одной опиокурильни и оставалось тогда только иметь наблюдение со стороны администрации, чтобы опиокурильни не открывались бы вновь, что при содействии китайского общества не составило бы особых затруднений». Он также очередной раз высказал мнение, что для достижения благоприятных результатов борьбу с опиокурением «нужно вести самым беспощадным образом, т. е. накладывать самые суровые судебные или административные взыскания на лиц, обличенных в содержании опиокурилен, продавцов разного рода принадлежностей к опиокурению и самих курильщиков опиума», а также «всех лиц прямо или косвенно уличенных в покровительстве опиокурению, как-то: домов-
4 Так должность названа в тексте источника, в действительности Председатель Сoвета министров. 
ладельцев и их квартиронанимателей и служащих при опиокурильнях...» (РГИА ДВ. Ф. 702. Оп. 3. Д. 151. Л. 118-119об.).

Накануне завершения своей службы в Приморской области В. Е. Флуг в секретном представлении от 27 ноября 1909 г. № 361 на имя генерал-губернатора сделал последнюю попытку убедить его в пользе легализации опиокурилен и банковок в целях борьбы с коррупцией полиции, при этом предложив «обложить его высоким акцизом, что, удорожая его стоимость, сделало бы его в тоже время менее доступным для широких слоев китайского населения». По мнению губернатора, «главным препятствием для успеха борьбы несомненно служит несочувствие к ней широких слоев китайского населения, а отчасти и сплоченность притоносодержателей, отсутствие надежных переводчиков и недостаточные штаты полиции, чины коей фактически не могут уследить за изнанкою жизни многотысячного китайского населения. Несомненно, что во многих случаях имеет значение и корыстолюбие низших чинов полиции...». Он писал, что опыт четырёхлетнего управления областью, убедил его, «что при тех средствах, которыми ныне располагает областная администрация, борьба с указанными язвами в жизни китайцев является совершенно непосильной. Между тем, нельзя и мириться с таким положением дела, которое является постоянным подрывом нашего государственного престижа среди иностранцев и источником развращения нравов нашей полиции и некоторой части русского населения» (РГИА ДВ. Ф. 702. Оп. 4. Д. 708. Л. 3-4об.).

Главный вопрос, который невозможно прояснить однозначно при анализе материалов данного дела, - это действительные мотивы участников эксперимента по легализации опиокурения во Владивостоке. Как и во всех остальных делах с участием китайцев и полиции вырисовывается присутствие двух заинтересованных сторон, каждая из которых настаивает на праведности своих мотивов и корысти другой стороны. Одна сторона, названная нами условно «Китайцы из Харбина», настаивает, что Лединг, разрешив открыто содержать в г. Владивостоке опиокурильни, тем самым отравляет китайцев, главным же мотивом его является увеличение «доходов русского правительства». При этом возможным скрытым мотивом письма является введенная Ледингом монополия на опиокурение и потеря доходов другими китайцами и стоящими за ними полицейскими чинами. Китайцы из Харбина фактически обвиняют полицмейстера, что он пошёл по тому же пути, что и П. В. Шкуркин, который обещал (или якобы обещал) содержателям тайных притонов легализовать бизнес за 12 тыс. руб. [10, с. 26-27]. Лединг на практике легализовал опиокурение, и невозможно поручиться, что за этим не стоял его сговор с китайцами - содержателями опиокурилен с целью монополизации «нелегального бизнеса» и концентрации большей части доходов в руках ограниченной части китайской верхушки и получения полицмейстером «больших откатов». Другая сторона - Лединг и связанные с ним китайцы - настаивала, что их усилия направлены лишь на постепенное избавление китайцев от наркотической зависимости и полное искоренение в городе опиокурения, а главное, взяточничества полиции. Ведь наличие тайных притонов служило почвой для постоянного мздоимства околоточных и городовых, очистить же ряды 
полиции было нерешаемой задачей, ибо на место одних мздоимцев приходили другие.

Опыт легализации был кратковременным и потому недостаточным для оценки его эффективности для борьбы с опиокурением и взяточничеством полиции. Он был прекращен по независящим от участников обстоятельствам - по решению коменданта крепости, но полицмейстер и военный губернатор были убеждены в его результативности. В. Е.Флуг и Г. И. Лединг были сторонниками ужесточения наказания и привлечения к ответственности за содержание притонов не только содержателей таковых, но и домовладельцев и арендаторов зданий, в которых таковые были найдены полицией, - наложение штрафов или заключение под арест в отношении русских подданных, иностранцев же кроме того необходимо было подвергать высылке на родину. Однако в тот момент Приамурский генерал-губернатор не согласился с ними, и они на свой страх и риск пошли на такой экстраординарный шаг.

\section{Литература}

1. Буяков А. М. Наркобизнес в Приморье и на Дальнем Востоке России: исторический экскурс в проблему // Записки Общества изучения Амурского края. Владивосток, 1992. Т. 28. С. 61-69.

2. Буяков А. М., Буяков О. А. Китайская полиция во Владивостоке в начале XX в. // Записки Общества изучения Амурского края. Владивосток, 2000. Т. 34. С. 69-79.

3. Граве В.В. Китайцы, корейцы и японцы в Приамурье // Труды Амурской экспедиции. СПб., 1912. Вып. 11. 480 с.

4. Губернии Российской империи. История и руководители. 1708-1917. М.: МВД России, 2003. 479 с.

5. Крестьянников Е. А. «Подпольная адвокатура» и консультации поверенных в дореволюционной России: из сибирского опыта // Российская история. 2010. № 4. C. $167-177$.

6. Нестерова Е.И. Русская администрация и китайские мигранты на юге Дальнего Востока России (вторая половина XIX - начало XX вв.). Владивосток: Издво ДВГУ, 2004. 372 с.

7. Синиченко В. В. Правонарушения иностранцев на востоке Российской империи во второй половине XIX - начале XX веков. Иркутск: Восточно-Сибирский институт МВД России, 2003. 192 с.

8. Сорокина Т.Н. «Взаимное соглашение о спирте и опиуме»: опыт совместной борьбы России и Китая с контрабандой в начале XX в. // Миграции и диаспоры в социокультурном, политическом и экономическом пространстве Сибири. Рубежи XIX-XX и XX-XXI веков. Сб. науч. ст. / Науч. ред. В. И. Дятлов. Иркутск: Оттиск, 2010. С. 229-251.

9. Позняк Т. 3. Китайские иммигранты и коррумпированность чиновников на российском Дальнем Востоке в начале XX века // Ойкумена. Регионоведческие исследования. 2011. № 3. С. 80-89.

10. Позняк Т. 3. «Культурные брокеры» и межкультурное взаимодействие в пространстве трансграничья во второй половине XIX- начале XX в. // Известия Восточного института. 2016. № 2 (30). С. 21-33.

11. Позняк Т. 3. «Русская полиция в погоне за китайским рублем»: история о том, как отставной полицейский боролся с мздоимством полиции и китайскими притонами в Благовещёнске (1914 год) // Новый исторический вестник. 2018. № 1 (55). C. $38-70$.

12. Позняк Т. 3. Борьба региональной администрации с опиекурением на российском Дальнем Востоке в конце XIX начале XX вв. и изучение опыта стран Восточной и Юго-Восточной Азии // Актуальные проблемы изучения истории стран ATP в XIX - XXI вв. Вып. III. Сб. науч. ст. Хабаровск, 2019. С. 249-269.

13. Шахерова С. Л. Дореволюционная адвокатура Восточной Сибири (18851917 гг.): Дис. ... канд. ист. наук. Иркутск, 2001. $346 \mathrm{c}$. 


\section{Tatiana Z. POZNYAK,}

Ph. D. (in History), Senior Research, Institute of History, Archeology and Ethnography of the Peoples of the Far East, FEB RAS (Vladivostok, Russia).

E-mail: tzpoznyak@mail.ru

\section{The Experience of Legalizing Opioid Smoking in Vladivostok at the Beginning of the 20th Century}

UDC 947.084.34(571.6)

Far East,

Vladivostok,

migration,

Chinese migrants, opioid smoking,

police,

corruption
DOI https://doi.org/10.24866/2542-1611/2021-1/6-19

The article is devoted to one episode from the history of the long struggle against opioid smoking and secret Chinese dens in the Russian Far East in the second half of the 19th - early 20th centuries. Representatives of the authorities and society proposed various ways to solve the problem, but the fight against opioid smoking was not effective. Some representatives of the regional administration and the public saw one of the ways to solve the problem of brothels in the legalization of opiocules and gambling houses. Supporters of the idea of legalizing opioid smoking considered it a panacea for bribery of local police, merging it with organized Chinese crime and a way to get rid of dens. Military Governor of the Primorsky Krai and Chief of Police of Vladivostok were not the pioneers, proposing in 1907 to legalize opiokurilnye (opium smokehouses), but they were the only authorities in the pre-revolutionary period who implemented such a method of fighting secret dens in practice, albeit for a short time.

For citation: Poznyak T. Z. The Experience of Legalizing Opioid Smoking in Vladivostok at the Beginning of the 20th Century // Oriental Institute Journal. 2021. № 1. P. 6-19. DOI https://doi.org/10.24866/2542-1611/2021$1 / 6-19$

\section{References}

1. Buyakov A. M. Narkobiznes V Primor'e i na Dal'nem Vostoke Rossii: istoricheskij ehkskurs v problemu // Zapiski Obshhestva izucheniya Amurskogo kraya. Vladivostok, 1992. T. 28. S. 61-69.

2. Buyakov A. M.,

Buyakov O. A. Kitajskaya politsiya vo Vladivostoke $v$ nachale XX v. // Zapiski Obshhestva izucheniya Amurskogo kraya. Vladivostok, 2000. T. 34. S. $69-79$.

3. Grave V. V. Kitajtsy, korejtsy i yapontsy v Priamur'e // Trudy Amurskoj ehkspeditsii. SPb., 1912. Vyp. 11. 480 s.

4. Gubernii Rossijskoj imperii. Istoriya i rukovoditeli. 1708-1917. M.: MVD Rossii, 2003. 479 s.

5. Krest'yannikov E. A. «Podpol'naya advokatura» i konsul'tatsii poverennykh v dorevolyutsionnoj Rossii: iz sibirskogo opyta
// Rossijskaya istoriya. 2010. № 4. S. 167-177. 6. Nesterova E. I. Russkaya administratsiya i kitajskie migranty na yuge Dal'nego Vostoka Rossii (vtoraya polovina XIX - nachalo XX vv.). Vladivostok: Izd-vo DVGU, 2004. $372 \mathrm{~s}$.

7. Sinichenko V. V. Pravonarusheniya inostrantsev na vostoke Rossijskoj imperii vo vtoroj polovine XIX - nachale XX vekov. Irkutsk: Vostochno-Sibirskij institut MVD Rossii, 2003. 192 s.

8. Sorokina T. N. «Vzaimnoe soglashenie o spirte i opiume»: opyt sovmestnoj bor'by Rossii i Kitaya s kontrabandoj v nachale XX v. // Migratsii i diaspory v sotsiokul'turnom, politicheskom i ehkonomicheskom prostranstve Sibiri. Rubezhi XIX-XX i XX-XXI vekov. Sb. nauch. st. / Nauch. red. V. I. Dyatlov. Irkutsk: Ottisk, 2010. S. 229- 
251.

9. Poznyak T.Z. Kitajskie immigranty i korrumpirovannost' chinovnikov na rossijskom Dal'nem Vostoke v nachale XX veka // Ojkumena. Regionovedcheskie issledovaniya. 2011. № 3. S. 80-89.

10. Poznyak T. Z. "Kul'turnye brokery» i mezhkul'turnoe vzaimodejstvie v prostranstve transgranich'ya vo vtoroj polovine XIXnachale XX v. // Izvestiya Vostochnogo instituta. 2016. № 2 (30). S. 21-33.

11. Poznyak T.Z «Russkaya politsiya v pogone za kitajskim rublem»: istoriya o tom, kak otstavnoj politsejskij borolsya $\mathrm{s}$ mzdoimstvom politsii i kitajskimi pritonami v Blagoveshhyonske (1914 god) // Novyj istoricheskij vestnik. 2018. № 1 (55). S. 38-70. 12. Poznyak T.Z. Bor'ba regional'noj administratsii s opiekureniem na rossijskom Dal'nem Vostoke v kontse XIX - nachale XX vv. i izuchenie opyta stran Vostochnoj i YUgo-Vostochnoj Azii // Aktual'nye problemy izucheniya istorii stran ATR v XIX - XXI vv. Vyp. III. Sb. nauch. st. KHabarovsk, 2019. S. 249-269.

13. SHakherova S. L. Dorevolyutsionnaya advokatura Vostochnoj Sibiri (18851917 gg.): Dis. ... kand. ist. nauk. Irkutsk, 2001. $346 \mathrm{~s}$. 